\title{
OBITUARY: Professor Richard Martin Harrison
}

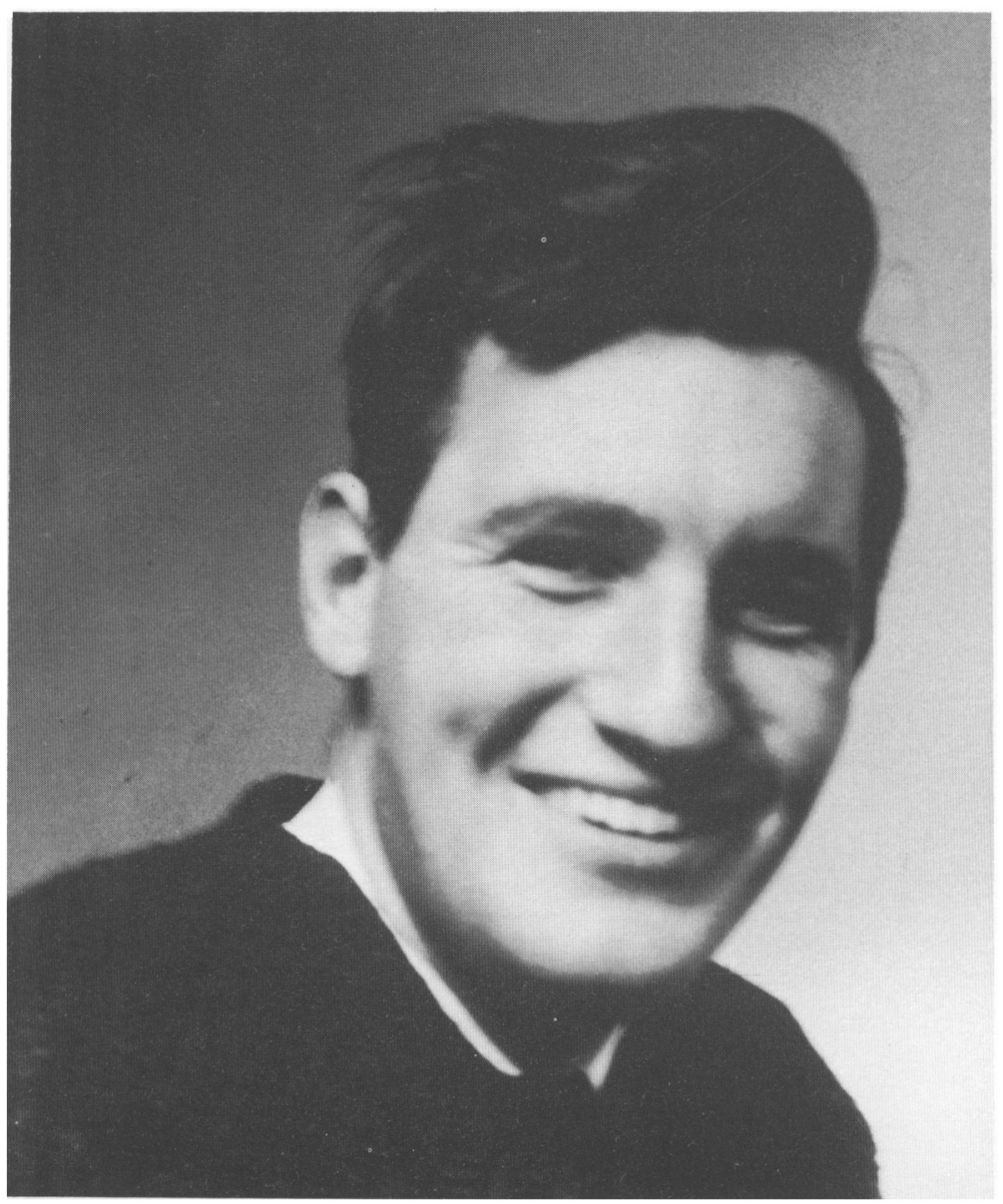

Martin Harrison, Professor of the Archaeology of the Roman Empire at Oxford and formerly Professor of Archaeology at Newcastle upon Tyne, died in September 1992 at the too early age of 57 . He had been a member of the Society for Libyan Studies since its foundation and sat on the Council from 1985 to 1989; for, although the main areas of his fieldwork were in Turkey, he always felt a lively interest in Libya, deriving from the year 1960/1 which he spent as Acting-Controller of Antiquities in Cyrenaica during Richard Goodchild's absence in East Africa. In other accounts of him his achievements in Turkey (a survey of churches in Lycia, the excavation of the great church of St. Polyeuktos at Istanbul, towards the end of his life the exploration of the Byzantine city of Amorium in Phrygia) have rightly pre-empted attention; here it is proper to expand on the year in Cyrenaica. The appointment was a challenge to a young man, taken up with spirit both by Martin and by his wife Elizabeth, who shared with him an adventurous outlook and a facility for meeting the unexpected with humour. He soon acquired a knowledge of Cyrenaica's antiquities, including those on many rural sites as well as in the cities, was sensitively observant of local life-styles, of geography, climate, botany and zoology, and quick to see what was relevant in them all to the comprehension of the ancient as well as the 
modern world in the territory. Moreover he directed - and published - three excavations for the Department of Antiquities, in the House of the Orpheus Mosaic at Ptolemais, in the sixth century church at Ras el Hilal, and in the Greco-Roman Theatre at Apollonia (where, although the second season was directed by Goodchild, it was Harrison who wrote up the findings). The first two of these, being on late antique sites, particularly engaged his interest, attracting him not only as part of Cyrenaican history but for their relevance to the transformation of the classical into the medieval world in the eastern Mediterranean. All three are early demonstrations of his characteristic vigour, the precision of his work and his imaginative insight; much remains to be done to find a fuller context for them, as he was well aware, but he has provided a good basis. His affection for the country and the people whom he met there was real and expressed itself later very notably in the help that he gave to a number of young Libyans who came to the Department of Archaeology which he developed in Newcastle upon Tyne and found there an encouraging environment in which to study for doctorates.

He is to be remembered as a man who splendidly enjoyed the use of his intellectual and physical powers, and would not let them waste even after he suffered a serious stroke in 1986; as an understanding friend and as a genial host. He died in his sleep, shortly after returning from (and completing a preliminary report on) a particularly happy and successful season at Amorium. 